\section{Effect of Nitrogen Source and Timing on Highbush Blueberry Performance}

\author{
Eric J. Hanson and Jorge B. Retamales ${ }^{1}$ \\ Department of Horticulture, Michigan State University, East Lansing, \\ MI 48824-1325
}

Additional index words. Vaccinium corymbosum, fertilization

\begin{abstract}
Bluecrop' highbush blueberries (Vaccinium corymbosum L.) received various $\mathbf{N}$ fertilizer treatments for 5 years. Treatments were evaluated by measuring berry yields and leaf $\mathbf{N}$ levels annually and bush size after 5 years. Nitrogen fertilizers increased yields and leaf $\mathrm{N}$ levels compared with nonfertilized controls. Split applications of urea (half applied at budbreak, half at petal fall) resulted in $10 \%$ higher yields than the same amount in a single application at budbreak. Urea and two controlled-release fertilizers (CRF) with different dissolution rates ( 3 to 4 months, 8 to 9 months) resulted in similar yields and leaf $\mathrm{N}$ levels when compared at the same rate of $\mathrm{N}$. The dissolution rate of the CRF materials did not affect yields or leaf $\mathrm{N}$ levels.
\end{abstract}

Efficient use of $\mathrm{N}$ fertilizers is increasingly important in crop production systems due to concerns over nitrate contamination of water resources. Blueberries are shallowrooted plants (Abbott and Gough, 1987) that are usually grown in Michigan on relatively sandy soils with perched water tables. Mature highbush blueberries in Michigan typically require annual applications of $70 \mathrm{~kg} \mathrm{~N} /$ ha (Hancock and Hanson, 1989) and recover only about one-third of the $\mathrm{N}$ applied as urea in a single spring application (Retamales and Hanson, 1989). Increased $\mathrm{N}$ levels below the blueberry root zone (Retamales and Hanson, 1990) indicate that leaching losses contribute to the low efficiency of current fertilization practices.

Practices that increase the percentage of applied $\mathrm{N}$ that is used by blueberry bushes (efficiency) may reduce production costs and potential impacts on water quality. Multiple or split applications may extend the time when applied N is available to plants. Split applications of urea resulted in slightly higher yields of highbush blueberries than single applications (Hancock and Hanson, 1986). Controlled-release fertilizers (CRF) have increased fertilizer use efficiency in various horticultural crops (Maynard and Lorenz, 1979). Sulfur-coated urea applications resulted in higher yields of young highbush blueberry bushes than ammonium sulfate (Brown et al., 1988), although sulfur-coated urea and urea were equally effective $\mathrm{N}$ sources for lowbush blueberries (Blatt, 1983; Sma-

Received for publication 3 Apr. 1992. Accepted for publication 15 July 1992. Acknowledgement is made to the Michigan Agricultural Experiment Station for support of this research. The cost of publishing this paper was defrayed in part by the payment of page charges. Under postal regulations, this paper therefore must be hereby marked advertisement solely to indicate this fact. 'Current address: Escuela de Agronomia, Universidad de Talca, Talca, Chile. gula and Hepler, 1978). In Germany, a controlled-release fertilizer appeared to stimulate more growth on highbush blueberries than ammonium sulfate-nitrate (Naumann and Kruger, 1985). Under greenhouse conditions, rabbiteye blueberry (Vaccinium ashei Reade) plants fertilized with sulfur-coated urea produced more growth than plants receiving ammonium sulfate, presumably because sulfur-coated urea had less effect on soil $\mathrm{pH}$ and electric conductivity (Patten et al., 1988).

Alternative fertilization practices need to be justified economically before commercial adoption could be expected. Most controlled-release $\mathrm{N}$ fertilizers are more expensive $\mathrm{N}$ sources than traditional fertilizers such as urea or ammonium sulfate. Multiple fertilizer applications represent additional costs to growers as well. This study was conducted to compare the effectiveness of two controlled-release fertilizers and split applications of urea to single applications of urea. The effects of treatments on soil and leaf $\mathrm{N}$ levels during the first two seasons were described by Retamales and Hanson (1990).
The study was conducted in a 1978 planting of 'Bluecrop' in Grand Junction, Mich., on a Kingswell-Pipestone complex (mesic entic haplaquods-mesic Mollic Psammaquents) sandy loam soil, with a mineral component composed of $78 \%$ sand, $12 \%$ silt, $10 \%$ clay, $7 \%$ to $9 \%$ organic matter, cation exchange capacity of 22 to $25 \mathrm{meq} / 100 \mathrm{~g}$, and a $\mathrm{pH}$ of 4.3. The following seven treatments were repeated each year from 1986 to 1990: 1) single urea, one application of 76 $\mathrm{kg} \mathrm{N} / \mathrm{ha}$ (2N rate) at budbreak; 2) split urea, two applications of $38 \mathrm{~kg} \mathrm{~N} / \mathrm{ha}(1 \mathrm{~N})$ at budbreak and petal fall; 3) CRF 3 months, conduration (Osmocote 19:6:12; Sierra Chemical, Milpitas, Calif.) at $1 \mathrm{~N}$ rate applied at budbreak; 4) CRF 3 months, $2 \mathrm{~N}$ rate applied at budbreak; 5) CRF 8 months, controlledrelease fertilizer with an 8-month release duration (Osmocote 17:6:10) at $1 \mathrm{~N}$ rate applied at budbreak; 6) CRF 8 months, $2 \mathrm{~N}$ rate applied at budbreak; 7) control (no N). Superphosphate and $\mathrm{KCl}$ were applied at budbreak to urea and control plots to supply $\mathrm{P}$ and $\mathrm{K}$ at rates similar to those contained in the 3month (19:6:12) and 8-month (17:6:10) CRF fertilizers.

Plots consisted of two bushes each, with one or more buffer plants between plots. Treatments were replicated 10 times in a randomized complete-block design. Fertilizer was spread by hand in a 60 -cm-wide band beneath bushes and was not incorporated into the soil.

Standard disease and pest control practices were used. Herbicieds were used to maintain a vegetation-free $1.5-\mathrm{m}$-wide strip beneath the plants. A stand of native grasses and other species was managed between the rows by periodic mowing. Bushes were pruned each year by removing damaged or less vigorous canes.

Leaf samples consisting of 24 leaves per plot were collected each year between late July and early August. Leaves were dried at $60 \mathrm{C}$, ground in a Wiley mill to pass through trolled-release fertilizer with a 3-month release

Table 1. Effect of $\mathrm{N}$ treatments applied from 1986 to 1990 on yield of 'Bluecrop' highbush blueberries.

\begin{tabular}{|c|c|c|c|c|c|c|}
\hline \multirow[b]{2}{*}{ Treatment $^{2}$} & \multirow{2}{*}{$\begin{array}{c}\text { Rate } \\
\text { (kg N/ha) }\end{array}$} & \multicolumn{5}{|c|}{ Yield (kg/bush) } \\
\hline & & 1987 & 1988 & 1989 & 1990 & Total \\
\hline Control & 0 & 0.31 & 0.88 & 1.56 & 1.67 & 4.42 \\
\hline Urea, single & 70 & 0.29 & 1.19 & 1.85 & 2.57 & 5.90 \\
\hline Urea, split & 70 & 0.42 & 1.46 & 1.83 & 2.71 & 6.42 \\
\hline \multirow[t]{2}{*}{ CRF $3-4$ month } & 35 & 0.47 & 1.11 & 1.73 & 2.27 & 5.58 \\
\hline & 70 & 0.40 & 1.39 & 2.06 & 2.31 & 6.16 \\
\hline \multirow[t]{2}{*}{ CRF 8-9 month } & 35 & 0.27 & 1.05 & 1.38 & 2.32 & 5.02 \\
\hline & 70 & 0.46 & 1.51 & 1.96 & 2.63 & 6.56 \\
\hline \multicolumn{7}{|l|}{ Contrasts } \\
\hline \multicolumn{2}{|l|}{ Control vs. $\mathrm{N}$} & NS & $* *$ & $*$ & $* *$ & $* *$ \\
\hline \multicolumn{2}{|l|}{ Single vs. split } & NS & NS & NS & NS & $*$ \\
\hline \multicolumn{2}{|l|}{ Urea vs. CRF } & NS & NS & NS & $*$ & NS \\
\hline \multicolumn{2}{|l|}{ CRF duration } & NS & NS & NS & NS & NS \\
\hline \multicolumn{2}{|l|}{ CRF rate } & NS & $*$ & $*$ & NS & $*$ \\
\hline
\end{tabular}

${ }^{2} \mathrm{CRF}$, controlled-release fertilizer.

Ns.*,**Nonsignificant or significant at $P=0.05$ or 0.01 , respectively. 
Table 2. Effect of $\mathrm{N}$ treatments (1986-90) on leaf $\mathrm{N}$ levels and growth of 'Bluecrop' highbush blueberries.

\begin{tabular}{|c|c|c|c|c|c|c|c|c|c|}
\hline \multirow[b]{2}{*}{ Treatment $^{z}$} & \multirow{2}{*}{$\begin{array}{c}\begin{array}{c}\text { Rate } \\
(\mathrm{kg} \mathrm{N} / \mathrm{ha})\end{array} \\
\end{array}$} & \multicolumn{5}{|c|}{$\begin{array}{l}\text { Leaf } N \text { concn } \\
(\% \text { dry wt })\end{array}$} & \multirow{2}{*}{$\begin{array}{c}\text { Bush ht } \\
\text { (m) }\end{array}$} & \multirow[b]{2}{*}{ Cane no. } & \multirow{2}{*}{$\begin{array}{c}\text { Total cane } \\
\text { cross-sectional } \\
\text { area }\left(\mathrm{cm}^{2}\right) \\
\end{array}$} \\
\hline & & 1986 & 1987 & 1988 & 1989 & 1990 & & & \\
\hline Control & 0 & 1.51 & 1.29 & 1.60 & 1.38 & 1.52 & 1.82 & 31.3 & 20.6 \\
\hline Urea, single & 70 & 1.58 & 1.50 & 1.74 & 1.42 & 1.73 & 1.88 & 32.2 & 22.9 \\
\hline Urea, split & 70 & 1.62 & 1.50 & 1.84 & 1.44 & 1.74 & 1.86 & 35.7 & 24.0 \\
\hline \multirow[t]{2}{*}{ CRF 3-4 month } & 35 & 1.62 & 1.41 & 1.68 & 1.42 & 1.70 & 1.78 & 30.1 & 21.9 \\
\hline & 70 & 1.53 & 1.34 & 1.81 & 1.43 & 1.71 & 1.93 & 32.1 & 23.1 \\
\hline \multirow[t]{2}{*}{ CRF 8-9 month } & 35 & 1.43 & 1.36 & 1.70 & 1.40 & 1.65 & 1.84 & 30.2 & 21.0 \\
\hline & 70 & 1.56 & 1.34 & 1.82 & 1.43 & 1.73 & 1.91 & 32.6 & 23.6 \\
\hline \multicolumn{10}{|l|}{ Contrasts } \\
\hline Control vs. N & & NS & $* *$ & * & ** & $* *$ & NS & NS & ${ }^{*}$ \\
\hline Single vs. split & & NS & NS & $* *$ & NS & NS & NS & NS & NS \\
\hline Urea vs. CRF & & NS & $* *$ & NS & NS & NS & NS & NS & NS \\
\hline CRF duration & & $*$ & NS & NS & NS & NS & NS & NS & NS \\
\hline CRF rate & & NS & ** & NS & *** & NS & ${ }^{*}$ & ${ }^{*}$ & ${ }^{*}$ \\
\hline
\end{tabular}

${ }^{2} \mathrm{CRF}$, controlled-release fertilizer.

NS.***Nonsignificant or significant at $P=0.05$ or 0.01 , respectively.

a $0.6-\mathrm{mm}$ (40 mesh) screen, and digested in a block digester in concentrated $\mathrm{H}_{2} \mathrm{SO}_{4}$, using $\mathrm{K}_{2} \mathrm{SO}_{4}$ and $\mathrm{Se}$ as catalysts. Total $\mathrm{N}$ concentrations were determined with a Quikchem flow injection analyzer (Lachat Instruments, Mequon, Wis.), using a Kjeldahl method (Lachat method 13-107-06-2-B).

Berries were picked by hand to measure yield. Bush size was assessed in Sept. 1990 by recording the height of the tallest cane per bush and measuring the diameter of all canes 10 to $14 \mathrm{~cm}$ above the ground. Cane count and diameter were used to calculate total cane cross-sectional area per bush.

All data were subjected to analysis of variance, and the following orthogonal contrasts were used to determine treatment differences: 1) control vs. $\mathrm{N}$, unfertilized control vs. all N treatments; 2) single vs. split, single urea application vs. split urea; 3) urea vs. CRF, single and split urea vs. CRF (3and 8-month duration) at $2 \mathrm{~N}$ rate; 4) $\mathrm{CRF}$ duration, CRF 3-month duration (1N and $2 \mathrm{~N})$ vs. CRF 8-month duration ( $1 \mathrm{~N}$ and $2 \mathrm{~N}$ ); 5) $\mathrm{CRF}$ rate, $\mathrm{CRF}$ products at $1 \mathrm{~N}$ rate vs. $\mathrm{CRF}$ at $2 \mathrm{~N}$ rate.

Weather during the growing seasons varied from relatively cool and moist (1986, $1989,1990)$ to warm and dry $(1987,1988)$. Precipitation during the growing season (MayAugust) totalled 570, 420, 180, 510, and $470 \mathrm{~mm}$ during 1986 to 1990 , respectively. Yields were not measured in 1986 because a freeze in early May killed nearly all flower buds. Yields were substantially reduced in 1987 by freeze injury to flower buds the previous winter (Table 1). Relatively low yields in 1988 were probably the result of extremely high temperatures and low rainfall during that growing season.

Nitrogen applications increased annual yields in 1988, 1989, and 1990 and total cumulative yield over nonfertilized controls (Table 1). Nitrogen applications also increased leaf N levels each year except 1986 and total cane cross-sectional area per bush by the end of the study (Table 2). Average leaf $\mathrm{N}$ levels over the five years were slightly lower than the optimum level of $1.65 \%$ pro- posed by Eck (1977) for blueberry leaves $(1.46 \%$ in control bushes, $1.58 \%$ in fertilized bushes).

Split applications of urea were slightly more effective than single applications. Bushes fertilized with urea at budbreak and petal fall produced $10 \%$ higher total yields than bushes receiving the same amount of fertilizer in a single application at budbreak (Table 1). Split applications, however, only resulted in higher leaf N levels than single applications in 1988 and did not affect bush height or cane crosssectional area (Table 2). Split applications of urea have increased blueberry yields compared with single applications in an earlier study (Hancock and Hanson, 1986) and are recommended for blueberries on sandy soils that are prone to leaching (Cain and Eck, 1966; Hancock and Hanson, 1986). This study was conducted on a sandy loam soil with a relatively high organic matter content and cation exchange capacity. Split applications might be more beneficial on more leachable soils lower in cation exchange capacity.

A problem with split urea application is that the second application at petal fall often is made in early to mid-June, when air temperatures in southern Michigan can be relatively high (25 to 33C). Significant portions of urea applied to the soil surface could be lost through volatilization as ammonia if the fertilizer is not incorporated. Although in this study we attempted to apply urea before predicted rains, this may not always be commercially practical.

Urea and CRF appeared to be equally effective when identical rates of $\mathrm{N}$ were compared. Although urea treatments resulted in slightly higher yields than CRF in 1990, total yields were nearly identical (Table 1). Similarly, urea and CRF resulted in similar leaf N levels each year except 1987, when ureatreated bushes contained higher $\mathrm{N}$ levels (Table 2).

Bushes receiving 3- and 8-month duration CRF produced similar yields (Table 1) and contained similar leaf $\mathrm{N}$ levels each year, except 1986 (Table 2). Reduced rates of CRF fertilizers $(1 \mathrm{~N})$ resulted in lower yields (Ta- ble 1) and often lower leaf $\mathrm{N}$ levels (Table 2 ) than full rates $(2 N)$. By the end of 5 years, bushes receiving $1 \mathrm{~N}$ rates of CRF were also shorter, with fewer canes and less total cane cross-sectional area (Table 2). These CRF materials were more expensive per unit of $\mathrm{N}$ than urea. Urea would be the preferred $\mathrm{N}$ source, since both appeared equally effective.

Other CRF materials may be more suited to blueberries than those used in this study. Between $45 \%$ and $47 \%$ of the $\mathrm{N}$ in these products was in the nitrate form, the remainder as ammonium. Since blueberries absorb $\mathrm{NH}_{4}-\mathrm{N}$ more rapidly than $\mathrm{NO}_{3}-\mathrm{N}(\mathrm{Pe}-$ terson et al., 1988), and $\mathrm{NO}_{3}-\mathrm{N}$ leaches more readily in soils, a CRF material that supplies all $\mathrm{N}$ as $\mathrm{NH}$, such as sulfur-coated urea, may have been more effective than the CRF materials used in these studies. CRF materials may affect plant growth differently by altering soil $\mathrm{pH}$ or electric conductivity (Patten et al., 1988). However, we did not measure soil chemical properties at the end of this study.

The duration or dissolution rate of these CRF materials ( 3 to 4 and 8 to 9 months) may not have closely matched the $\mathrm{N}$ uptake pattern of blueberries. Greatest recovery of fertilizer $\mathrm{N}$ would be expected when the release rate coincides with periods of greatest crop uptake (Maynard and Lorenz, 1979). Although we found no reports describing the seasonal pattern of $\mathrm{N}$ uptake by mature blueberry bushes, highest uptake might be expected when shoots and roots are growing most rapidly. This occurs during the 4 weeks following petal fall, although growth may continue at reduced rates until fall (Abbott and Gough, 1987). A CRF material that released $\mathrm{N}$ over 2 to 3 months, with the most rapid release during the first 2 months, might fit the uptake pattern of blueberries. However, further work is needed to describe the annual $\mathrm{N}$ uptake pattern of blueberries.

This study indicates that split applications of urea increase blueberry yields over single applications. Two CRF materials tested here were as effective as urea as $\mathrm{N}$ sources for 
blueberries, although their cost would not allow widespread commercial use.

\section{Literature Cited}

Abbott, J.D. and R.E. Gough. 1987. Seasonal development of highbush blueberry roots under sawdust mulch. J. Amer. Soc. Hort. Sci. 112:6062.

Blatt, C.R. 1983. Management practices and marketable yields of lowbush blueberries. HortScience 18:938-940.

Brown, G.R., D. Wolfe, and M. Rasnake. 1988. Comparison of two nitrogen fertilizer sources for highbush blueberries. HortScience 23:314315 .

Cain, J.C. and P. Eck. 1966. Blueberry and cranberry, p. 101-129. In: N.F. Childers (ed.). Fruit nutrition: Temporate to tropical. Horticultural
Publications, Rutgers The State Univ., New Brunswick, N.J.

Crocker, T.E. 1983. Use of sulfur coated urea, ammonium sulfate and urea phosphate on blueberries in Florida for $\mathrm{N}$ and $\mathrm{pH}$ control. Proc. Fla. State Hort. Soc. 96:226-227.

Eck, P. 1977. Nitrogen requirement of the highbush blueberry, Vaccinium corymbosum L. J. Amer. Soc. Hort. Sci. 102:816-818.

Hancock, J.A. and E.J. Hanson. 1986. Highbush blueberry nutrition. Mich. State Univ. Ext. Bul. E-2011, East Lansing.

Maynard, D.N. and O.A. Lorenz. 1979. Controlled-release fertilizers for horticultural crops. Hort. Rev. 1:79-140.

Naumann, W.D. and E. Kruger. 1985. Nitrogen supply of highbush blueberries. Acta Hort. 165:229-236

Patten, K.D., V.A. Haby, A.T. Leonard, E.W. Neuendorff, and J.V. Davis. 1988. Nitrogen source effects on rabbiteye blueberry plant-soil interactions. Commun. Soil Sci. Plant Anal. 19:1065-1074.

Peterson, L.A., E.J. Stang, and M.N. Dana. 1988. Blueberry response to $\mathrm{NH}_{4}-\mathrm{N}$ and $\mathrm{NO}_{3}-\mathrm{N}$. J. Amer. Soc. Hort. Sci. 113:9-12.

Retamales, J.B. and E.J. Hanson. 1989. Fate of ${ }^{15} \mathrm{~N}$-labeled urea applied to mature highbush blueberries. J. Amer. Soc. Hort. Sci. 114:920923.

Retamales, J.B. and E.J. Hanson. 1990. Effect of nitrogen fertilizers on leaf and soil nitrogen levels in highbush blueberries. Commun. Soil Sci. Plant Anal. 21:2067-2078.

Smagula, J.M. and P.R. Hepler. 1978. Comparison of urea and sulfur-coated urea as nitrogen sources for lowbush blueberries growing on a Colton gravelly loamy sand. J. Amer. Soc. Hort. Sci. 103:818-820. 